\title{
Exploring the Heroines Disguised as Men in Tanci from the Perspective of Space
}

\author{
Liyao Zhao ${ }^{1, *}$ \\ Xi'an Jiaotong University, No.28, Xianning West Road, Xi'an, Shaanxi, 710049, P.R. China \\ ${ }^{*}$ Corresponding author.Email: zly999999@stu.xjtu.edu.cn
}

\begin{abstract}
During the Ming and Qing Dynasties, it has created an unprecedented cult of female chastity. At the same time, a large number of female writers emerged. In Tanci with female writers as the main body of creation, female writers can only express their wishes, meritorious service and fame by transforming their heroines into male images, but even if this part of women's gender consciousness is burgeoning, they are still trapped in the inner chambers, don't have and men equal public space. Women who lack space for social space have private space instead, which has become a Utopia of creation, giving them a lot of space for creation.
\end{abstract}

Keywords: Tanci androgyny inner-chamber space.

\section{INTRODUCTION}

As a survey of the relevant texts indicates, a large number of female writers appeared during the late Ming and early Qing Dynasties. Women's writings through the ages in Past Dynasties by $\mathrm{Hu}$ Wenkai (1901-1988) contains 21 volumes, 15 of which are in the Qing Dynasty. There are more than 4,200 women whose works have been collected in all dynasties, including 361 before the end of Ming Dynasty and more than 3,800 in the Qing Dynasty. In addition, 118 people who are not included in Women's writings through the ages in Past Dynasties compiled by Ms. Shi Mei are nearly 4,000.

Among the female writers in the Ming and Qing Dynasties, there were a large number of boudoir poets, As Kang-i Sun Chang said, "no other nation has produced more anthologies or collections of women's poetry than late imperial China."[ Kang-i Sun Chang, Ming and Qing anthologies of women's poetry and their selection strategies, Writing women in late imperial China ed. Kang-i Sun Chang and Ellen Widmer Standford: Standford university Press, 1997, p. 147 recite Fong, Grace S, and Ellen Widmer. The Inner Quarters and Beyond: Women Writers from Ming Through Qing. Leiden: Brill, 2010. Print.] At the same time, Tanci, with women as the main body of creation, became a popular trend in the literary world. Tanci is an ancient traditional art, originated from Taozhen in the Song Dynasty and $\mathrm{Ci}$ in the Yuan and Ming Dynasties. It began to appear in the middle of the Ming Dynasty and flourished in the Qing
Dynasty. Tanci was one of the most influential and popular singing literature in the Qing Dynasty, leaving a strong mark in the history of Chinese literature. From the middle of the 17 th century to the beginning of the 20th century, there were as many as 400 kinds of Tanci works. There are as many as fifty or sixty kinds of Tanci works, which are novels of rhyme style. Among them, there are about thirty or forty works written by female writers, such as Dan jing chuan, Eternal Happiness, Phoenix Mountain, Adding Brocades to The Flowers, Rain Flowers and $\mathrm{Bi}$ shenghua, 19 female writers whose surnames can be examined include Tao Zhenhua, Chen Duansheng, Liang Desheng, and Hou zhi, etc.

With the change of Ming and Qing dynasties, the emergence of capitalist commodity economy has become a special period in Chinese history. At the same time, the role of women in the social structure is contradictory. On the one hand, Under the social orthodoxy of "NeoConfucianism", "It has created an unprecedented cult of female chastity in Chinese history."[1]; On the other hand, the development of capitalist commodity economy brings economic prosperity and social stability, "among other factors, that contributed to the growing prevalence of educating girls in elite families in some regions, particularly the Yangzi Delta area."[2]. Late Ming dynasty, as women began to accept education, and the rise of women culture personality liberation thoughts, repressed female consciousness emerged, but in late imperial China, the unity of the patriarchal and feudal monarchy rule, with the family construction level of the 
smallest unit of society, this leads to women in their own voice through the creation at the same time, this kind of writing space agency limited to purdah, could not have caused a big stir in the society, or that is the cult of female chastity under the oppression of women, female consciousness awakening, but the two conflicting, cannot make women represent sound. Women do not discourse power, which makes them a voiceless group and cannot be included by men or even the society.

In the patriarchal society of the late imperial China, their voices strayed into the gap between society and the family. In this social context, women could only express their personal thoughts and emotions through the identity or tone of men in their writings; therefore, the female protagonists of Tanci are heavily filled with the image of crossing over from physical women to men with social identities through changes in appearance, in order to achieve the goal of personal. Virginia Woolf (1882 - 1941) put forward the concept of "Androgyny" in A Room of One's Own, which established an important standard for feminist literary criticism. In Elaine Showalter's words, "feminists for doing an equality with men, and after a long time to imitate male values, and internalized, by the early 20th century, and finally found that women should be independent of men, and has its own value, thus entered a self-discovery and self-identity stage, they began to explore how to do women problem. "In the Tanci of the Ming and Qing Dynasties, the image of men given to women not only remained in imitation, or women for men "secondary", the most fundamental reason is that in the traditional feudal period, in most cases, the only male has social political, women's desire for fame, contributions can only be through the role of men realize personal ambition, under this kind of discourse, men's appearance is not only the embodiment of the physiological properties, it is a social and political status symbol, it is women' $\mathrm{s}$ desire to like men have equal rights consciousness. There are two types of hermaphrodites: the first is purely physical imitation, and the second is the imitation of a deeper political identity.

\section{THE PHENOMENON OF HEROINES DISGUISED AS MEN}

The practice of women disguised as men has been documented in many texts, in Tanci with women as the main body of creation, there is a writing technique named "imitator": Although the motivation and expression of imitator are different from the protagonists in Tanci, they grumble and dream of all the things that men have, that they can do, that they enjoy. Hua Wei, a famous opera critic, further defined the term "impersonating a man" as follows: "When a female writer becomes a protagonist in a drama, she retains her identity as a woman but appears in the form of a man. She plays the lead role and uses the identity of a man to express her feelings and narration."[ Hua,Wei. The Representation of "Masculinity" and Gender Issues in Women's Plays of the
Ming and Qing Dynasties: On "Yuanyang Meng," "Prosperous Meng," "Qiao Ying," and "Lihua Meng" [C] Preparatory Office of the Institute of Chinese Literature and Philosophy, Academia Sinica The Proceedings of the International Symposium on Ming and Qing Opera: Next, 1998: 573]

As a survey of the relevant historical texts indicates, the most famous of which is The Ballad of Mulan: "the male rabbit's feet move quickly, the female keeps her eye shut, but if they run together, can you tell if I'm a he or she". According to Nanshi: "In the past, there was a woman named Loucheng in Dongyang. She disguised herself as a man, so she travelled among the princes at that time. Later, Lou became an official in Yangzhou. When the woman disguised herself as a man was discovered, Emperor Ming sent her back to his hometown". She changed into women's clothes and left, sighed: "Although I have such a ability, but still have to dress up as an old woman, it is really a pity." [3]

It can be observed that when female shed their disguised masculine appearance, their previous social identity is also lost. In Ming and Qing Dynasties, records of women dressing as men began to increase, according to the record, women dressed up as men studied with him "Yingtai, is the daughter of Shangyu local Zhu family, disguised as a man to go out to study, and will be called Liang Shanbo will study together." [Tian,Yiheng. Liuqing Rizha]

In The Chronicle of Ye Tianliao, there is also a record of women disguised as men, not only that, but also an increase in the description of female talent: Guisheng, who is poor and childless, there is only one daughter who is very beautiful, and she pretends to be a man without letting people know that she is a woman, and she is good at poetry and ancient literature. [Ye, Shaoyuan. A Chronicle of Yetianliao]

In Eternal Happiness, Meng Lijun who, the heroine of the novel, refuses to yield to the authority of the Liu family and refuses to marry. She then runs away from home, disguised herself as a man and attains fame in capital city. She disguised herself as a man by the girl of the boudoir into a young prime minister, the state of mind has also changed subsequently. She by the original reality forced to change, and with the idea of revenge for the husband's family, gradually changed their own ideas, "The girl is a wonder to be born with this talent."From being under pressure to be a man to using his male identity to fulfill his personal ambitions. And while she achieved reputation, underneath this pride, she could not hide her regret that women could not achieve the same level of fame as men: "The champion scholar sat in the saddle with his sleeves hanging down, floating on the top of the nine curves of yellow roses. The number of people in front of and behind the crowd, full of spring breeze proudly. The jade whip flicked the red robe sleeves, secretly pleased with the high ranking standing in the 
palace hall. Previously, the cloud bun and gold hairpin hidden embroidery; today, the red robe and hat as a hero." [4]

Another female character is even more daring in Eternal Happiness. She does not obtain merit by taking exams, but, like Mulan, establishes prestige for herself through warfare. The seventeen-year-old Wei Yong'e fled in male disguise, which describes her image as a warrior: "The golden armor hangs from her body, and her hair tied to the sides of the forehead. The gold thread is thinly coiled red arrow sleeves, the war dress lightly covered with brocade cloud robe. Pink-soled boots on the feet, belt half hanging waist. The left side secretly wears the green blade sword, the right rear of the head hanging gold-backed large sword." [ ibid]

The other kind of hermaphrodite can be further seen as women' $\mathrm{s}$ desire to participate in politics. In the Jinxiang yiyong zhou is the appearance and behavior is linked together: "Dai su xian as a man's outfit, waist bow with the arrow across the horse, build a flag, call a thousand people knot Yong camp, protect the village, thieves dare not commit."[5]

Or desire to defend the country through the war, in Tian yuhua: "The iron heart, a piece of loyalty to serve the country. The pearly curtains and painted buildings are in sight. Eight hundred princes have their hands tied, and three thousand soldiers are subordinate to the thieves." [6]

As the writer portrays the external image and behavior of women, it then turns to resentment of the oppression suffered because of gender.

To Wai- yee Li, women's discontent with the limits of gender roles at this historical juncture could become the precondition and impetus for, or the consequence of, political engagement. Their articulation of valor foreshadows the strong voice of social criticism and political consciousness in a later generation of women writers as they witnessed the devastating disorder of the nineteenth century[Fong, Grace S, and Ellen Widmer. The Inner Quarters and Beyond: Women Writers from Ming Through Qing. Leiden: Brill, 2010. Print, p. 13]

In Rain Flowers, the author of the feudal criticism: "I am sorry that I have tangled feet, but I was allowed to discuss my heart, saying that I have the talent of Mulan and the will and deeds of Cao E. I am deeply ashamed"

There is also a critique of women's foot binding habit in the Jing huayuan: "I heard that there was a woman's foot binding at the honor, and when it began to be wrapped, the woman suffered in all kinds of torture, holding feet and crying, and even the skin rotted and the flesh was broken, and the blood was dripping. At this time, cannot sleep at night, food does not swallow, a variety of diseases, resulting in. Who knows that this is for the beauty, if not, that is, not for the beauty. The nose is large cut to make small, high forehead cut to make flat, people must be called cruel people, why two feet crippled, walking difficult, but also for the beauty? Even if the King of the West is the most beautiful, and had to cut off half of its two feet? Moreover, if we look at the reason, how is it different from making obscene objects? This is the reason why saints must be punished, the reason why the wise do not take. But the gentleman of the world, to end its habits, this culture can be gradually restored."

\section{CONCLUSION}

Compared with the public space, the space where the female writers are located is more private, and this private space can be divided into abstract space and physical space.

On the one hand, for some feminist critics, the "Wilderness" became the site of truly women-cantered criticism, theory, and art. Showalt was positive about the status of the woman who Adena used the word "wild filed" to mean "voiceless". She thinks that the conception of the so-called "wild filed" woman's text is just playing with the abstract concept. In the reality that we must face when we call ourselves a critic, women' s creation is a "double voice discourse", which always appears the dual tradition of losing voice and dominating society, literature and culture.

However, the "wilderness" can be seen as a space for women, and the women of the Ming and Qing dynasties were in the deep harem, and their voices could only be heard between the family and society, but at the same time, this also gave them enough space for activities. As Francesca Bray discusses the space in which women live in Technology, Gender and history in Imperial China, "Spatial isolation protects against those inescapable pressures and temptations of men, allowing them to acquire purer, transcendent virtues."[ 7]

On the other hand, according to a picture of residence of the well-bred lady by C.A.S. Williams in 1976, the first dwelling at the main entrance was the outer courtyard, which served as a place to receive guests, while the inner courtyard led to the "inner chamber", the private space reserved for women. It is noteworthy that each courtyard is composed of four rows of enclosed rooms, so this dwelling can be roughly divided into three separate parts, and the inner chamber, which is at the deepest part of the courtyard, is isolated from the public space of the outside world. Further, the subject is completely unable to transcend, and loses the ability to grasp the cognitive public space. The private space completely transcends the subject and keeps the subject firmly within itself, but at the same time, women are also free in this private space.

It is worth noting that such ladies are from prestigious families, hence they have more opportunities to education, take an example as Chen Duansheng who, the author of Eternal Happiness, was born in a eminent family in Hangzhou. His grandfather Chen Zhaolun was 
the a successful candidate in the highest imperial examinations. Chen received informed education since childhood and his thoughts were relatively progressive, however, after seven years of marriage, Fan who was Chen's husband convicting of cheating in an examination in Shun Tian and sent to Yili, which was a big blow to Chen Duansheng. After that, Chen went back to create, devoting more time and experience to her writing instead of her family. The female images in the novel are opposed to the traditional thought that men are inferior to women and women cannot achieve great achievements, and they believe that their behaviours cannot be bound by gender. Additionally, according to the historical documents, Qiu Xinru who wrote $\mathrm{Bi}$ shenghua, at the beginning of the book, she writes: "I don't know how bitter the world is, but I know that I was born with ink and literature.. I like to read my father's books and read the ancient history, and I am more interested in my mother's teachings."[ Qiu Xinru: Bi shenghua, Zhengzhou: Zhongzhou Ancient Books press, 1984 edition]

Qiu Xinru began to write at the age of 15." However, from the end of the fifth chapter of Bi Sheng Hua, a large number of unsatisfactory words about life appeared in the autobiographical writings. At this time of Qiu Xinru has been married, is the interruption of nineteen years to recreate, in the book she wrote 'busy in the final volume, is already nineteen years long'. After get married 19 years later, with her back sister showed her 'New Poetry', a book of natural paint edge to let her 'She began to turn over the original work in the study and reviewed the written documents. "'[Shi Xiaolan. Research on Qiu Xinru and "Brush Living Flower" [D]. Nanjing Normal University,2014.]

The fierce spirit of women in late imperial China was in conflict with cross-dressing, women' $s$ desire to participate in political activities and women's rebellion against feudal traditions. However, the foot-binding and loyalty behaviors of women in the Ming and Qing Dynasties were more for the purpose of building a family reputation for being named in the Lie Nü Zhuan. In fact, the fundamental purpose of both is for women to have social identity, rather than to be trapped in the boudoir, but in different ways. As Guo Moruo said: "She used feudal morality to oppose the feudal order, and used nobility, rank and title to oppose the superiority of men and women." In the preface to the adaptation of Eternal Happiness, the preface argues that "the protagonist Meng Lijun is a rebel against the traditional feudal concepts and the feudal system, but she still uses the weapon of feudalism"[8]. However, under the social background at that time, Chen Duansheng could only express his dissatisfaction with the persecution of women by feudal ethics by endowing women with male images, realizing his ambition and showing his talent, but the premise was to speak as a man. From the boudoir to the society, the female gender consciousness is slowly emerging.
During the Ming and Qing dynasties, a part of women' $s$ gender consciousness emerged. They could not become officials through the imperial examinations or defend the country by joining the army like men did. The best way is to dress up as men, get the same social status as men, and then participate in social activities. For women on the margins of society, it was this gap that provided them with a certain amount of private space, which in turn facilitated their creativity and the awakening of their gender consciousness[9].

\section{REFERENCES}

[1] Wu, Cuncun. Ming qing Shehui Xingai Fengqi. Peking: People's Literature Publishing House, 2000. Print, p. 17

[2] Fong, Grace S, and Ellen Widmer. The Inner Quarters and Beyond: Women Writers from Ming Through Qing. Leiden: Brill, 2010. Print

[3] Li, Yanshou. Nan Shi. 1975. Print.

[4] Chen, Duansheng. Eternal Happiness Quan Zhuan: 20 Juan. Beijing: Beijing Ai ru sheng shu zi hua ji shu yan jiu zhong xin, 2009. Internet resource.

[5] Li, Ruzhen. Jing Hua Yuan: 20 Juan. Beijing: Beijing Ai ru sheng shu zi hua ji shu yan jiu zhong xin, 2011. Internet resource.

[6] Taozhenhuai. Rain Flowers. Zhengzhou: Zhong zhou gu ji chu ban she, 1984. Print.

[7] Bray, Francesca. Technology, Gender and History in Imperial China. London: Taylor \& Francis Ltd, 2013. Print.

[8] Hu, Wenka, and Hongsheng Zhang.Li Dai Fu Nu Zhu Zuo Kao. Shanghai: Shanghai gu ji chu ban she, 2008. Print

[9] Mann, Susan. Precious Records: Women in China's Long Eighteenth Century. Stanford, Calif: Stanford Univ. Press, 1997. Print. 